\author{
RANDALL N. STUBBS, YEN-LIN GOH \\ Cultural Arts Centre, Tumaini University Makumira \\ Usa River, Tanzania \\ Passiontree Music, Kuala Lumpur, Malaysia \\ ORCID:0000-0003-3258-5747,manager@cac.makumira.ac.tz \\ ORCID: 0000-0002-8993-1340,yenlin.goh@gmail.com
}

\title{
The Cultural Arts Centre at Tumaini University Makumira in Tanzania: Educational Research in Action
}

The Cultural Arts Centre (CAC) and the Department of Music at Tumaini University Makumira collaborated for a comprehensive project to improve the Tanzanian musical educational system reflecting the local cultural context. The problems with the present-day state of music education include a lack of teachers, resources, and opportunities. The five phases of this project include a pilot music programme at a local government school, the Uraki Secondary School, mapping study of traditional music in the area, field research to gather traditional music, formal and informal educational opportunities for the youth, and developing music curriculum resources. After years of continuous effort the results are many, showing that this project is an important step forward for the country. This project is ongoing and is expected to be expanded to other schools, create collaborative partnerships with other academic institutions, and ultimately advocate for changes in the national curriculum of Tanzania.

Keywords: curriculum development, music education, Tanzania, traditional music, Tumaini University Makumira.

For citation / Для циитирования: Stubbs Randal N., Yen-Lin Goh. The Cultural Arts Centre at Tumaini University Makumira in Tanzania: Educational Research in Action // Проблемы музыкальной науки / Music Scholarship. 2020. № 4. C. 97-113.

DOI: 10.33779/2587-6341.2020.4.097-113.

\section{РЭНДАЛЛ Н. СТАББС, ЕН-ЛИН ГО}

Центр культуры и искусств, Университет Тумаини Макумира

2. Уса Ривер, Танзания

«Passiontree Music», г. Куала-Лампур, Малайзия

ORCID: 0000-0003-3258-5747,manager@cac.makumira.ac.tz

ORCID:0000-0002-8993-1340,yenlin.goh@gmail.com

\section{Центр культуры и искусств при Университете Тумаини Макумира в Танзании - о развитии музыкального образования}

Центр культуры и искусств (САС) и Музыкальный факультет Университета Тумайни Макумира разработали совместный комплексный проект по совершенствованию системы музыкального образования Танзании, отражающей местный культурный контекст. Проблемы с музыкальным образованием включают в себя нехватку учителей, ресурсов и возможностей. Пять этапов этого проекта имеют пилотную музыкальную программу в правительственной школе, средней школе Ураки, картографическое изучение традиционной 
музыки в этом районе, полевые исследования для сбора традиционной музыки, формальные и неформальные образовательные возможности для молодёжи и разработку ресурсов музыкальной учебной программы. После многих лет непрерывных усилий были получены многочисленные результаты, свидетельствующие о том, что проект является для страны важным шагом вперёд. Проект развивается и, как ожидается, будет распространён на другие школы, создаст партнёрские отношения сотрудничества с рядом академических учреждений. В конечном итоге, он будет способствовать внесению изменений в национальную учебную программу Танзании.

Ключевые слова: разработка учебных программ, музыкальное образование, Танзания, традиционная музыка, Университет Тумаини Макумира.

\section{INTRODUCTION}

\section{Music Education in Tanzania}

Tanzania is at a junction where local traditional culture and modern ideas from outside meet. After World War I, the British took over control of the "modern" schools built on Western European education system precepts previously established by the Germans and missionary organisations [24]. Today, these formal schools have almost entirely replaced traditional village education, except in some remote areas. Government schools revised their school curriculum in 1963, two years after independence, but made no changes to the British music curriculum that was already in place [15, p. 512]. In that system music was a compulsory subject in primary school [16, p. 37]. In 1992 the curriculum was revised and the number of subjects was reduced from 13 to 7 and music was removed [20, p. 67]. Today, music and dance are not offered in the government schools and in many private schools [6, p. 9]. Traditional music is perceived by many to be of little value and is inferior to music from outside Tanzania [11, p. 11].

\section{Uraki Secondary School}

Today, the official government music curriculum exists at the secondary school level as an optional subject and there is only one government school in the whole country that takes the national music examinations [12]. That school, Uraki Secondary School, has been the subject of a music pilot programme initiated by the late Carol Stubbs (2018), former lecturer from the Department of Music at Tumaini University Makumira (TUMa), in 2013. This study has provided significant practical information regarding the feasibility and challenges of establishing a music programme in a school.

Uraki Secondary School was identified as the initial school for this programme for four main reasons. One, it is close to Tumaini University Makumira, about one kilometre from the university entrance. This allows easy access not only for the TUMa lecturers, but also for the music students to participate in the teaching at Uraki as part of their training, and for Uraki students to attend special workshops and performances at TUMa. Two, the selected school ranked in the bottom $10 \%$ in national examination results in every subject area ${ }^{1}$. If there could be some success at this school it could provide a positive model for the other schools.

Three, the school lacked in most resources normally required for a good teaching environment. The unconducive classroom environment with broken concrete floors, limited number of desks and chairs for the students, missing windows, 
no electricity, no printed resources, and no drinking water available would prevent others from suggesting success was due to abundant resources (which, unfortunately, are lacking in most government schools in Tanzania).

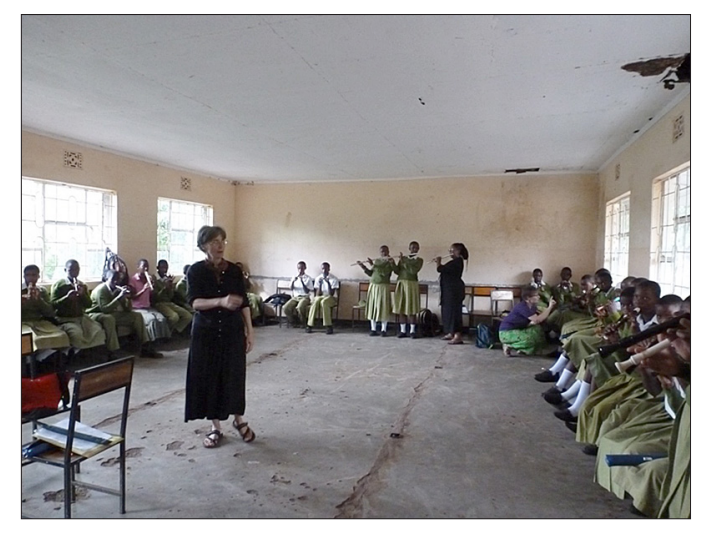

Figure 1. Uraki Secondary School Classroom with the late Carol Stubbs

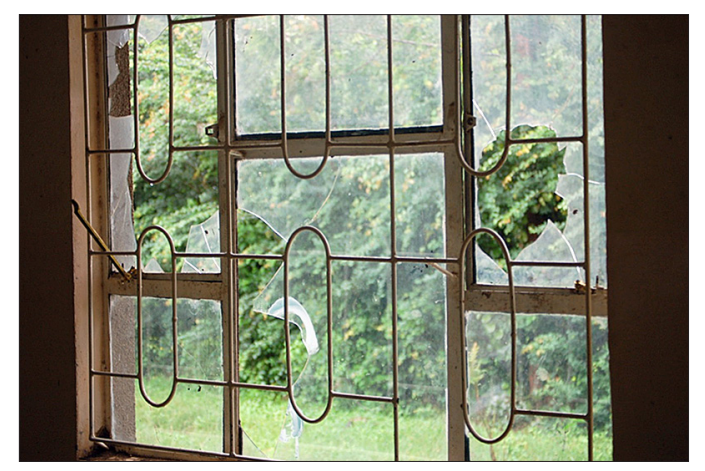

Figure 2. Uraki Secondary School classroom for music with broken windows

Lastly, the self-esteem and motivation level of the students at Uraki were low, because they knew that very few students passed the national examinations and had any chance of going on for further education. Students who do not pass the national exams most often end up unemployed, working as house girls/boys, getting pregnant, being married off (arranged marriage), or work only as casual day labourers $[1 ; 5]$. In short, for these students, there was not much hope for any kind of successful life by most standards.

\section{Tumaini University Makumira}

In 2006-2016, Tumaini University Makumira (TUMa) was the first and only university to offer a Bachelor's degree in music. Over the past 13 years, TUMa has produced 90 music graduates with a primary emphasis in music education. These graduates were required to take intensive music education courses and to undergo practical teaching training. The music curriculum includes both African and Western content. As an illustration, there are three years of African music history and African ensembles while there is one year of European music history. In addition, there is also a series of required courses in the music history of North and South America, Asia and the Middle East, American jazz, and church music. All music students also take Western music theory, choir (singing music from all over the world), and introductions to piano, guitar, recorder, trumpet, and drum set. Other required courses include stage production, audio and video production, composition/arranging, and music business courses.

The music department is unique not only in terms of the programme offered, but also the faculty make-up compared to the other departments at TUMa and the other universities in Tanzania. Over the past 11 years there have been music lecturers from America (6), Sweden (1), German (3), Finland (5), and Malaysia (1) working alongside Tanzanians to create a collaborative faculty trying to bring the best of cultures and ideas together.

In Tanzanian villages, traditional elders would want to keep their music and culture alive, but the current education system seems to be working against them. The Cultural Arts Centre (CAC) at TUMa, which was initiated by the music department, started in 2014. It is specifically working to preserve 
and promote traditional music and dance in Northern Tanzania.

Through this research, which includes development of curriculums and outreach programmes for the children and the youth in Northern Tanzania, the CAC and Department of Music at TUMa are striving to make a positive contribution to music, education, and traditional cultures in Tanzania. This is educational research in action, for the benefit of the students and the local and international communities.

\section{PROBLEM STATEMENT}

At the foundational level there are two basic and interconnected problems. One, some traditional cultures in Tanzania are lost permanently, and at an alarming rate [3; 4]. Two, students and youth are becoming more and more disconnected from their own traditional culture. The researchers believe these may be due in part to the current "modern" education process that has replaced traditional village education for the past several generations.

There are various factors affecting the loss of traditional culture in Tanzania. Many of these factors resemble those found in other developing countries around the world [21]:

1. Nearly all of the traditional music and dance exist only in aural form. In Northern Tanzania there is very little scholarly research and documentation on the music and dance of the three most populous ethnic groups, namely the Maasai, Meru, and Chagga. Although one can easily find pictures of the Maasai in tourism brochures for Tanzania (and Kenya), their music and dances often appear as short random amateur videos on YouTube or Facebook, void of basic and useful academic research details [11].

2. The curriculum in Tanzania has music as an optional subject. Primary and secondary school students read stories, poems, and proverbs about various Tanzanian cultural concepts, but they rarely participate in the activities that previously surrounded the telling of those stories and poems. Traditional music and dance are not required and are not taught in government schools. They are only offered by few private schools and international schools [20].

3. The music curriculum in Tanzania focuses primarily on Western music theory, musical analysis, and listening skills following the British system and terminology. There are very few exam questions on Tanzanian instruments and local artists. Instrument playing or other practical skills are not usually evaluated in the school exams ${ }^{1}$.

4. It is a challenge for school teachers to find resources that would help them to teach Tanzanian music and dances. A teacher who wants to teach music in a government secondary school has to rely purely on his or her own experiences and intellect. There was no available published resources on Tanzanian dances and music (curriculum materials that include traditional songs) for the schools.

5. There are few qualified Tanzanian teachers who have sufficient knowledge and experience to teach traditional songs and dances in schools. As of 2017, this pioneering music degree programme at TUMa has only existed 11 years, producing a total of 61 music graduates in a country that has a population of nearly 55 million.

6. There are few positive role models of traditional music performers in the society. Only a handful of traditional performers earn a living with their skills in music and dance. The popular music industry in Tanzania emphasizes and promotes money, sex, and power. Therefore, most parents do not encourage their children to learn music.

7. Many people in the society view music purely as a talent and that musicians 
should not expect any money for sharing their talents. This makes it difficult for music teachers, church musicians, and music performers to earn a living. This is discouraging for those who may have a passion for music, and yet facing the reality of needing money to survive.

\section{AIM AND RESEARCH QUESTIONS}

The Cultural Arts Centre at Tumaini University Makumira aims to help preserve and promote traditional dance and music in Tanzania through active engagement with surrounding schools and communities and through the development of curriculum resources that teach musical and societal concepts using local traditional music.

Based on this aim, this project addresses four research questions:

1. Given an opportunity to learn about and participate in traditional music, will school children or students choose to become engaged in these activities?

2. If both traditional and Western music are taught, will the students be able to learn both local and Western music skills alike?

3. Given an opportunity to learn various music and dance at their school, will the students choose to remain more connected to their traditional culture?

4. Given the generally poor academic performance in all academic subjects, will experiencing success in the music classroom build self-esteem among these students?

It is hoped that ideas and templates developed in this pilot programme can be replicated and used in other schools in Tanzania and even other developing countries in Africa.

\section{LITERATURE REVIEW}

In the school setting, studying music improves problem solving, memory and verbal ability, language skills, and much more $[7 ; 14]$. For the purpose of this project by $\mathrm{CAC}$, the problem with such a study is that such studies were conducted in American schools with generally good infrastructure, teachers, instruments, and teaching in the first language of the students. These situations do not exist in Tanzanian government schools.

Dr. Mitch Strumpf has written a number of articles related to music education in African contexts. Notable for this project includes Music Education in Malawi and Zimbabwe [17], which advocates for programmes that include local cultural music and development of resources for the schools. His Different Approaches to Music Education in East Africa: The Past 100 Years gives a good overview of the history of music education in East Africa [18]. Unfortunately, in the final section on current activities in Tanzania, only projects that the author has personally participated are listed.

The Tanzanian national curriculum, Music syllabus for secondary schools: Form I-IV primarily emphasizes Western European music theory concepts without in Tanzania $^{2}$. The curriculum designed for this project has to follow the requirements set forth in this publication in order for it to be recognised by the government.

There is only one published general music theory book in Swahili: Mwanafunzi wa muziki (students of music). Despite the recent publication date, it looked like it was typeset with all hand-written musical examples taped in crooked manner onto the pages and the book was photocopied poorly. It only covers Western music theory concepts ${ }^{3}$.

In 2013, Music4One, a Korean NGO, created music curriculum materials for Tanzania. Their Flute Book 1 includes a few traditional and popular Tanzanian songs in addition to songs from other parts of Africa 
[2]. However, because the book does not adhere to the national curriculum it cannot be used for government schools. It can only be considered for private schools that do not take the national examinations. In fact, these materials created are geared for those learning Western instruments such as piano, flute, and violin.

Dr. Kedmon Mapana, a Tanzanian lecturer from the University of Dar es Salaam, wrote his $\mathrm{Ph} . \mathrm{D}$. dissertation on the attitude of music educators on the music curriculum for Tanzanian schools [9]. He articulated the background information related to some current challenges in music education in Tanzania. Unfortunately, this work was not yet available when the pilot programme at Uraki Secondary School and subsequent research at TUMa were developed.

With no music teachers in government schools and most private schools, there have been few attempts to using traditional Tanzanian songs in the education system. Ukuti, ukuti is a colourfully illustrated book of children's songs with printed melodies and a CD to help with performance aspects [8]. Even though it serves as a useful resource, it was not designed to be used formally with the national curriculum. A few other collections of Tanzanian folk songs were published abroad and in Tanzania, but they are intended for church use only.

The music pilot programme experiences at Uraki Secondary School spanning the past three years have become the most useful context-specific reference for the project conducted by the Cultural Arts Centre. As one of the schools in the bottom $10 \%$ nationally, Uraki represented the antithesis of the aforementioned study conducted with the American schools. Both the qualitative and quantitative information of this project have served as valuable resources and helped the researchers to determine how to move forward.

\section{METHODS AND SUMMARY OF FINDINGS}

The main methods used included case study, qualitative research, resource development, and experimentation.

\section{Phase I: \\ Uraki Pilot Programme in Music}

Given the challenging circumstances at Uraki Secondary School, when the case study began in 2013, the initial baseline was not surprising. The most vivid example was in Mathematics, whereby 114 out of 119 students who took the national exams scored less than $40 \%$ out of 100 . Swahili was the best with only 24 out of 119 students getting less than $40 \%$. Outside of music there was only one student who scored above $80 \%$ in any single subject. Table 1 shows the complete 2013 National Examination Council of Tanzania (NECTA) results of the Uraki Form II students, the initial target group for this project.

Table 1. Uraki Secondary School 2013

National Examination Council of Tanzania (NECTA) results

\begin{tabular}{|c|c|c|c|c|c|c|c|c|c|c|}
\hline \multicolumn{11}{|c|}{2013 Uraki Secondary School: FORM II Summary of Results } \\
\hline & $\frac{\tilde{U}}{3}$ & 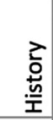 & 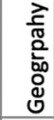 & 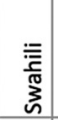 & $\begin{array}{l}\frac{\bar{c}}{\underline{\underline{m}}} \\
\underline{\underline{w}} \\
\underline{\mathrm{w}}\end{array}$ & 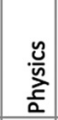 & 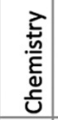 & 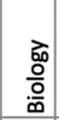 & $\begin{array}{l}\text { 吉 } \\
\text { 荧 }\end{array}$ & $\frac{u}{\underline{y}}$ \\
\hline Subject Average (/100) & 30 & 34 & 27 & 50 & 34 & 19 & 25 & 29 & 6.6 & 49 \\
\hline Subject Rank & 328 & 316 & 309 & 225 & 238 & 315 & 297 & 296 & 329 & 2 \\
\hline Out of overall Rank & 355 & 354 & 355 & 355 & 355 & 354 & 355 & 355 & 355 & 2 \\
\hline$A(80-100)$ & 0 & 0 & 0 & 0 & 1 & 0 & 0 & 0 & 0 & 2 \\
\hline B (60-79) & 2 & 5 & 6 & 26 & 10 & 1 & 6 & 5 & 1 & 9 \\
\hline C (40-59) & 15 & 30 & 17 & 69 & 25 & 4 & 14 & 16 & 4 & 18 \\
\hline $\mathrm{D}(30-39)$ & 34 & 34 & 17 & 12 & 25 & 10 & 21 & 23 & 4 & 11 \\
\hline$F$ & 68 & 50 & 79 & 12 & 58 & 104 & 78 & 75 & 110 & 3 \\
\hline Absent & 6 & 6 & 6 & 6 & 6 & 6 & 6 & 6 & 6 & 9 \\
\hline Sum & 125 & 125 & 125 & 125 & 125 & 125 & 125 & 125 & 125 & 52 \\
\hline
\end{tabular}

In January 2013, the late Carol Stubbs started an optional music class for Form II students, generally aged 15 to 16 . She volunteered her time to teach for one hour three times per week. Even though the 
students did not start with the Form I music syllabus, they sat for the national music exam in November. The results were very positive for the music subject as compared to all the other subjects. Since music was an optional subject, there were only 43 students who sat for the exams and two students scored above $80 \%$. The 14 students who scored below $40 \%$ were students who had not been attending classes. The results for the academic years of 2014 and 2015 were also very positive for music compared to other subjects (see NECTA results 2014 and 2015, Table 2 and 3). Unfortunately, in the past few years the Ministry of Education no longer published the rankings by subjects and by schools.

Table 2. Uraki Secondary School 2014 NECTA results

\begin{tabular}{|c|c|c|c|c|c|c|c|c|c|c|}
\hline \multicolumn{10}{|c|}{2014 Uraki Secondary School: FORM II Summary of Results FTSEE } & \multirow[b]{2}{*}{$\stackrel{\frac{u}{n}}{\Sigma}$} \\
\hline & $\frac{\tilde{U}}{3}$ & 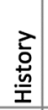 & 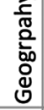 & 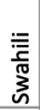 & $\frac{\bar{c}}{\frac{5}{00}}$ & $\frac{\tilde{n}}{\frac{n}{\tilde{n}}}$ & 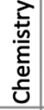 & $\begin{array}{l}\text { ठ̀. } \\
\frac{\mathrm{O}}{0} \\
\frac{0}{0}\end{array}$ & $\begin{array}{l}\mathbf{f} \\
\sum \\
\Sigma\end{array}$ & \\
\hline$A(80-100)$ & 0 & 0 & 0 & 0 & 4 & 0 & 0 & 0 & 0 & 5 \\
\hline $\mathrm{B}+(70-79)$ & 4 & 4 & 0 & 0 & 7 & 0 & 0 & 0 & 0 & 7 \\
\hline$B(60-69)$ & 10 & 6 & 1 & 2 & 6 & 0 & 0 & 2 & 0 & 7 \\
\hline C (50-59) & 15 & 7 & 4 & 17 & 13 & 0 & 4 & 4 & 2 & 7 \\
\hline D (40-49) & 12 & 21 & 11 & 45 & 14 & 2 & 3 & 9 & 2 & 9 \\
\hline$E(30-39)$ & 32 & 43 & 17 & 28 & 35 & 11 & 7 & 29 & 2 & 3 \\
\hline$F$ & 26 & 18 & 66 & 7 & 21 & 86 & 85 & 55 & 93 & 0 \\
\hline \multicolumn{11}{|l|}{ Absent } \\
\hline Sum & 99 & 99 & 99 & 99 & 100 & 99 & 99 & 99 & 99 & 38 \\
\hline
\end{tabular}

Table 3. Uraki Secondary School 2015 NECTA results

\begin{tabular}{|c|c|c|c|c|c|c|c|c|c|c|}
\hline \multicolumn{10}{|c|}{2015 Uraki Secondary School: FORM II Summary of Results FTNA } & \multirow[b]{2}{*}{$\frac{u}{n}$} \\
\hline & $\stackrel{u}{3}$ & 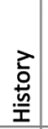 & 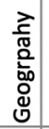 & 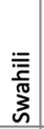 & 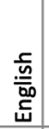 & $\begin{array}{l}\frac{n}{w} \\
\frac{\tilde{n}}{a}\end{array}$ & 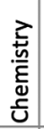 & $\begin{array}{l}\overrightarrow{0} \\
\frac{0}{0} \\
\frac{0}{0}\end{array}$ & $\begin{array}{l}5 \\
\sum \\
\sum\end{array}$ & \\
\hline$A(80-100)$ & 2 & 0 & 1 & 0 & 7 & 0 & 1 & 2 & 0 & 0 \\
\hline$B+(70-79)$ & 4 & 1 & 3 & 14 & 14 & 1 & 0 & 13 & 0 & 14 \\
\hline$B(60-69)$ & 13 & 5 & 6 & 21 & 16 & 1 & 2 & 13 & 1 & 18 \\
\hline$C(50-59)$ & 10 & 12 & 15 & 14 & 12 & 2 & 2 & 10 & 2 & 15 \\
\hline D (40-49) & 16 & 27 & 15 & 6 & 7 & 6 & 6 & 4 & 1 & 5 \\
\hline$E(30-39)$ & 12 & 16 & 10 & 6 & 4 & 28 & 18 & 14 & 3 & 1 \\
\hline $\mathrm{F}$ & 4 & 0 & 11 & 0 & 1 & 23 & 32 & 5 & 54 & 1 \\
\hline \multicolumn{11}{|l|}{ Absent } \\
\hline Sum & 61 & 61 & 61 & 61 & 61 & 61 & 61 & 61 & 61 & 54 \\
\hline
\end{tabular}

Traditional dance was added as an extra activity during the final quarter of the academic year and was made available to any students who wanted to participate. During the first rehearsal, a total of 160 students showed up, and this was many times more than what was expected. This was in fact contrasting to what was mentioned by the school officials on how the students were not interested in traditional music. Traditional dance was then included as part of the music teaching each year, with TUMa music students serving as teachers. By 2016 music was offered to Form I-IV as a class.

\section{Phase II: \\ Initial Mapping of Traditional Groups, Music and Dance}

With initial grant funding from the European Development Fund, the Cultural Arts Centre (CAC) at Makumira started its activities in early 2014 collaborating with the Department of Music and several local NGOs. The plan was to document and preserve the traditional cultures in Northern Tanzania through this field research of traditional songs and dances. This documentation would include audio and video recordings of traditional ceremonies in their original contexts and interviews with village leaders and traditional musicians.

The geographic focus for this project has been on the three primary ethnic groups found in Northern Tanzania, namely the Meru, Chagga, and Maasai. The region boundaries are from the Kenya border in the north to the Lake Manyara area in the south, and the Maasai areas from the Ngorongoro Crater in the west to the Pare Mountains in the east (see Figure 3). This entire region includes two famous mountains, Mt. Kilimanjaro, where the Chagga are the primary ethnic group, and Mt. Meru, where the Meru people are prevalent. The Maasai reside in all the other areas mentioned above (see Figure 4). 


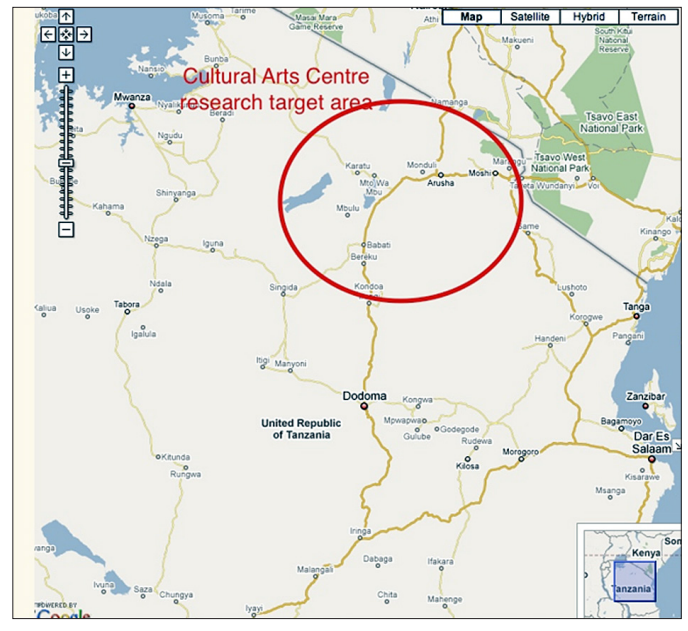

Figure 3. Map of the Cultural Arts Centre mapping and research area in Northern Tanzania (Google map)

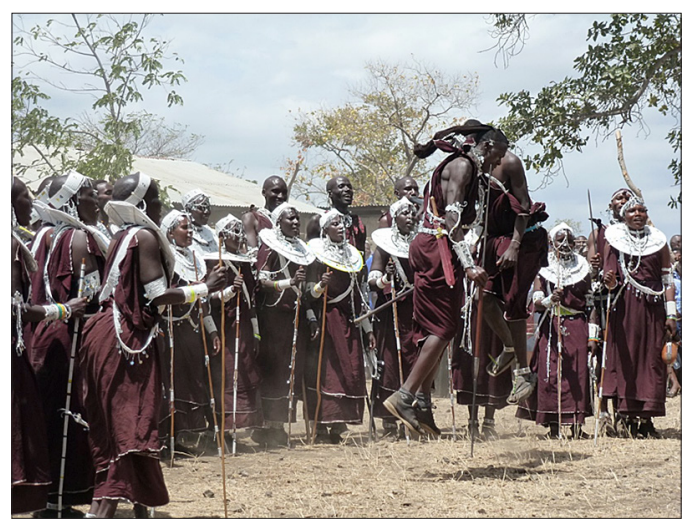

Figure 4. Maasai dancing

A three-person team from CAC, headed by Aliko Mwakanjuki, conducted a preliminary mapping from July to September of 2014 to determine how many groups were still performing traditional music and what music/dance have already been documented [11]. Through numerous visits to the abovementioned areas the CAC research team confirmed what was initially suspected. It was discovered that both the Chagga and the Meru have only two active traditional dance groups. The Maasai, however, have retained many of their traditional customs, costumes, and ceremonies up to present time. Many Maasai village settlers and family groups have individuals who are knowledgeable about their music and dances. The purpose of this initial study was to identify groups and to search for existing documentation only. The study was helpful and yielded many contacts that aided the following phases of the project.

\section{Phase III: Field Research and Documentation}

As of April 2016 the research team has collected 795 video clips comprised of various ceremonies, songs, dances, and interviews. This is in addition to materials that were previously collected by others in Tanzania. This documentation is foundational for the work of the Cultural Arts Centre, both in terms of informing the CAC dancers about performance practices of their music, and for the development of curriculum and educational resources for use in schools. Following this initial documentation, CAC has produced DVDs of the field research to give back to the village leaders who provided the music, dance, and interviews.

The CAC team has met with the directors from the International Library of African Music, claiming to be the largest archive of African music in the world. In addition, CAC has visited Rhodes University in Grahamstown, South Africa and the Klaus Wachsman Archives at Makerere University, Uganda to study and to learn some of the best practices for this research in Tanzania. CAC has created a database with the field metadata and short 10-15 second excerpts from various ceremonies and events of the Maasai, Meru, and Chagga groups. Currently, access to the full videos is available at the CAC facilities in Tanzania.

\section{Phase IV: Traditional Music and Dance Activities for Youth (Formal and Informal)}

Formal trainings organised by $\mathrm{CAC}$ included short courses in traditional dance 
and professional skills. Alliance FrancoTanzania Arusha assisted in conducting these formal trainings with the addition of local and international experts on various topics. The result of the first two formal dance trainings was the hiring of 15 fulltime dancers/musicians for CAC. After some intensive training and numerous performances (over 70 in the first year), these dancers/musicians then became the main teachers for subsequent dancer trainings held in 2016 for Form IV leavers (students who finished school, but did not necessarily graduate).

In July 2015, the Cultural Arts Centre began to promote traditional music in schools through traditional music and dance workshops and performances. This has been accomplished through traditional dance performances given by CAC dancers/ musicians at area government, private and international schools. These performances are offered free as part of CAC outreach into the community. For many of the government schools, it was the first time they have ever had a live professional performance at their schools.

Most of these performances took place in an open area outside or under some trees, which actually added to the authenticity. When performing songs and dances from local areas, students were invited to participate and they tend to participated in large numbers (see Figure 5 and 6). In addition, a number of CAC dancers/musicians have led traditional dance and drum workshops at various schools to help them prepare for special events such as graduation ceremonies. School administrators have been extremely cooperative and enthusiastic about these opportunities for their students and schools. Almost all of these schools have requested additional performances and workshops from CAC. As of June 2019, CAC has given a total of 69 school performances and multisession traditional dance workshops.

Most of these performances have taken place in an open area outside or under trees, which actually added to the authenticity. When performing songs and dances from local areas students were invited to participate and they participated in large numbers (see Figure 5 and 6). In addition, a number of CAC dancers/musicians have led traditional dance and drum workshops at various schools to help them prepare for special events such as graduation. School administrators have been extremely cooperative and enthusiastic about these options and possibilities for their students and schools. Almost all of these schools have requested additional performances and workshops from CAC. As of June 2019, CAC has given a total of 69 school performances and multi-session traditional dance workshops.

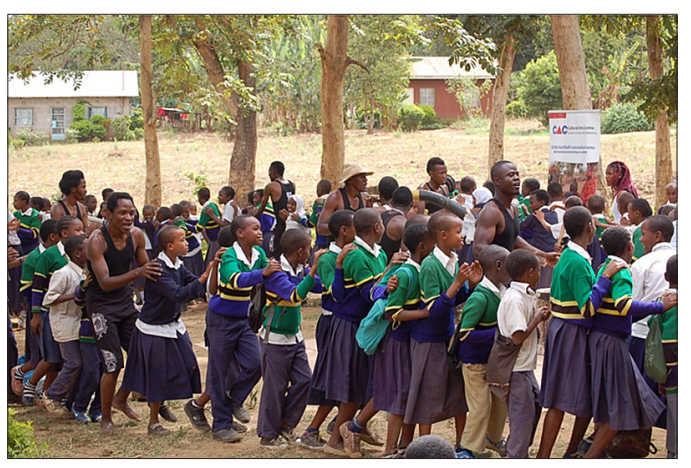

Figure 5. Cultural Arts Centre performance at Makumira Primary School under the trees

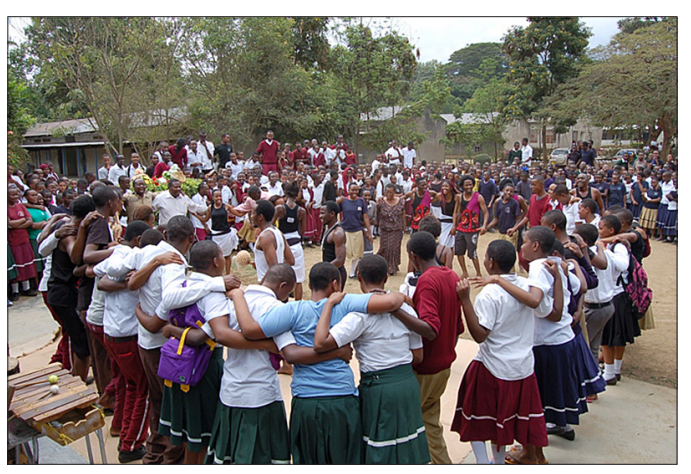

Figure 6. Cultural Arts Centre at Makumira Secondary School with students joining in a local dance 
Another aspect of the school outreach was the organizing of a school traditional dance competition in January 2016. Eight nearby schools were selected to participate in this competition. The CAC dancers/ musicians went to each of these schools for three weeks prior to the competition to help the students prepare and practise for the competition. The site of the competition was the new one-thousand-seat multi-purpose hall at TUMa, in which CAC had contributed by building a large dance stage in addition to professional sound, light, and projection systems along with some extensive acoustic work to ensure an excellent performance facility. On the day of the competition, the CAC research team documented the entire day's activities. DVDs of all the schools' performances along with some interviews were given to each school. For nearly all of the contestants it was their first time to be on a real stage, and to perform for a large audience. The level of performance was higher than expected, due primarily to the work of the CAC dancers/musicians with each school (see Figure 7 and 8).

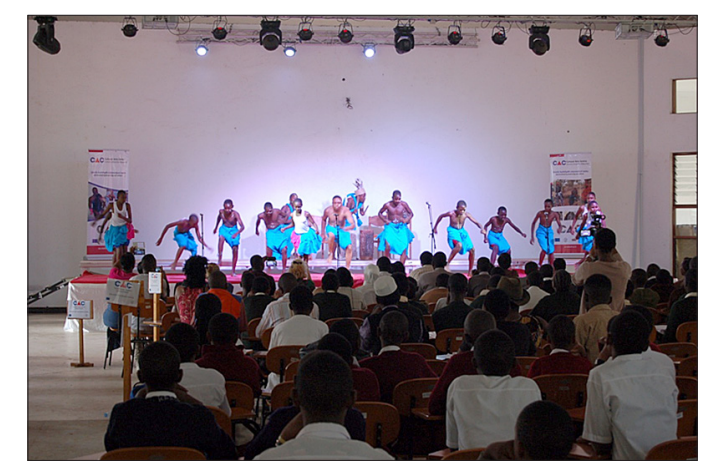

Figure 7. Cultural Arts Centre dance competition for schools in January 2016

Furthermore, CAC has given various community performances as part of its outreach. Performances have included welcoming all five East African Presidents, either at the airport or upon arrival for East African Community activities. CAC

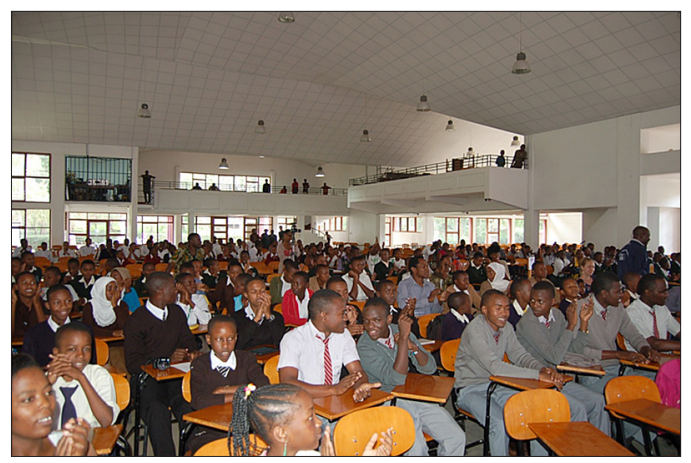

Figure 8. Cultural Arts Centre dance competition audience

has also given performances at the annual Uhuru (freedom) Torch celebrations, various tourism fairs, and other government and festival events. Many young people have had the opportunities to attend these activities and witness traditional music and dance performed at a high level.

\section{Phase V: \\ Developing Curriculum Resources}

Based on the various experiences and outcomes gathered from the Uraki pilot programme, the goal of this phase was to develop local resources for secondary schools that support the Tanzanian national music curriculum while reflecting the community culture.

From all the songs and dances gathered from the three primary ethnic groups documented by $\mathrm{CAC}$, the research team selected 60 songs to be used for developing music curriculum resources. Songs were selected mainly based on their message content, such as respecting elders, helping the community, HIV/AIDS prevention, while some songs were selected due to their usefulness in teaching musical concepts required by the national curriculum. Some of the songs have already been transcribed into Western music notation.

In all government schools in Tanzania, primary school education is conducted in Swahili while English is the required 


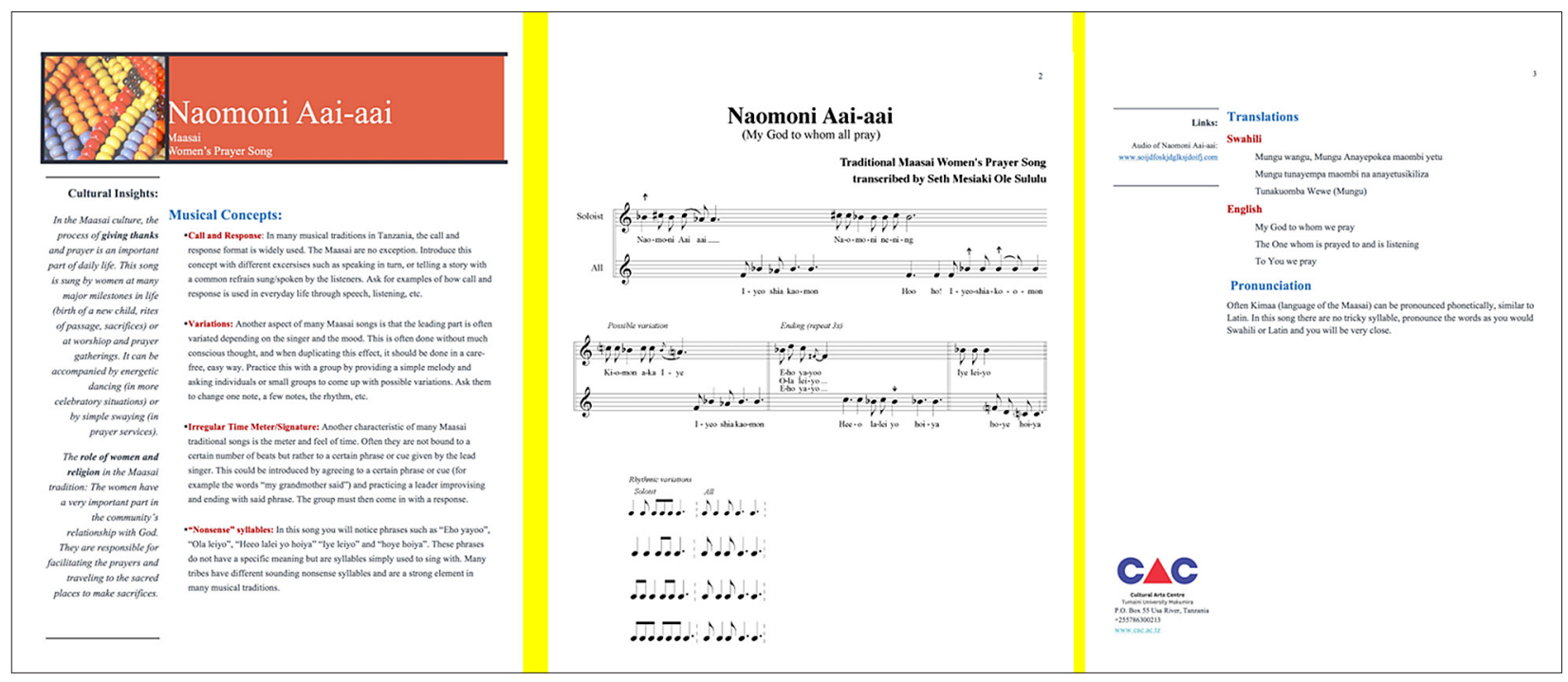

Figure 9. Sample of CAC music curriculum developed

language of instruction for all secondary schools in Tanzania. Elders from the various ethnic groups were consulted for the context of the songs, the original words in the vernacular language, and the translation into Swahili. The research team, assisted by local consultants, then provided an English translation and developed lesson plans and concepts based on each song. CAC has developed an initial music curriculum resource template and is currently at the evaluation stage (see Figure 9).

\section{ANALYSIS OF FINDINGS AND DISCUSSION}

There have been many expected results and other results that were different than expected. Analysis and discussion will follow the five phases of the project for more clarity.

\section{Phase I: \\ Uraki Pilot Programme in Music}

The sample of students having music as an examinable subject greatly exceeded expectations, and when the option for traditional music was added in, the response from students was even greater. This demonstrated a strong evidence that youths were still interested in traditional culture, despite not having the access to quality presentations on their own traditional culture within the government school system.

Students enrolled in the Uraki music classes for the first two years since the beginning of the programme have achieved a promising level in their traditional and Western music skills. Some of these Uraki graduates with music background have applied to enrol in the Certificate of Music programme at Tumaini University Makumira. This is a significant progress.

There are other exciting examples of success within this study. In 2015, several students did very well in their music exams, but failed all the other subjects, which prevented them from being able to continue their formal education. Nevertheless, these students were given an opportunity to assist in teaching current students music. With a passion for Western music, they have continued to learn informally through YouTube videos, printing out free sheet music and practising on their own. 
Prior to the establishment of the music subject at Uraki Secondary School, the students who failed in every subject were considered unintelligent and hopeless by their teachers. However, the fact that they could score "A" in music (but failed in all other subjects) shows that they could do well in a subject with proper training and effective teaching. Indeed, the time allotted for the music subject was less than all the other school subjects. This experiment also highlights the problems with the teachers in schools who may not understand the different ways students can learn. They often read from their notebooks and have the students copy and memorising for exams. The poor exam results show that this traditional way of teaching does not lead to understanding, comprehension, and true learning.

Music education is making a real and positive impact in the livelihood of students at the Uraki Secondary School, not just from the academic terms, but also to allow them to experience a boost in their morale and self-esteem in at least one part of their lives.

\section{Phase II: \\ Initial Mapping of Traditional Groups, Music and Dance}

The initial mapping confirmed what was suspected from the beginning. Most ethnic groups, including the Chagga and Meru, did not actively participate in traditional dance and music. The Maasai have retained more of their traditional music and culture. These were clearly visible in villages and even cities in Tanzania. Ceremonies were still abound and many Maasai participate in the various music and cultural activities.

The obvious limitation for this research is that if people do not remember their music and dances (because they are not using them in their lives) then conducting this meaningful research is quite difficult.
The researchers are certain that much music and dance are lost permanently, especially from the Meru and Chagga peoples. This is unfortunate and highlighting the importance of documenting what little traditional music and dance that are still remaining.

\section{Phase III: Field Research and Documentation}

Even though the research team has successfully accumulated hundreds of hours of video documentation of traditional events to date, there have been various challenges. First, the need of notification that events are happening. Second, was developing an understanding with the various communities that this documentation is for the benefit of the community and the country and not for the personal profit of researchers or documenters. And third would be the issue of authenticity.

From the beginning, CAC has tried to ensure the authenticity by appointing only Tanzanians to run the actual field research, which included two Maasai doing field research in the Maasai land, where the largest amount of information remains. One advantage of this autoethnographic study is that these Maasai team members understand their own heritage well and are accepted by the Maasai community. It should also be noted that all CAC team members hold at least a Bachelor's degree.

Another issue related to authenticity is documenting in the original context as much as possible. This means finding ceremonies and documenting them, rather than going to a village and asking people to perform music that is used at a certain ceremony. The latter is much easier to organise, but CAC feels that the act of finding ceremonies and documenting them is far more authentic. The challenge comes in getting good communication to find out when various ceremonies are taking place. 
The final issue related to authenticity is payment for information. It is relatively easy to find people who are willing to sing and/or dance when payment is offered, but then the researchers questioned whether they were getting authentic songs and dances when they did that. During the process of the initial mapping, it became evident that some of the existing documentation for the target area was not authentic. For example, Chagga musicians playing an American swing tune on home-made metal guitar and singing in the Chagga language is not authentic Chagga music, even though it is performed by the Chagga. From the CAC policy, it will not honour any payment for the initial data collection, but instead, offering the groups an opportunity to perform subsequently at the university with a payment. For the most part this has worked well in the field work.

\section{Phase IV: Traditional Music and Dance Activities for Youth (Formal and Informal)}

The importance of the school outreach programmes (informal education) cannot be over emphasised. For instance, when the students watch a CAC performance, they often get excited about their own music and dance. When they were asked before a performance if their traditional culture is important or not, most would say, "no," but when they were asked after witnessing a proper traditional performance, most of them said "yes." This result has been consistent in the government, private, and international schools. The attitude about the importance of traditions and culture must first happen with the younger generation in order to create a long-term change.

CAC realised even more now that practical music and dance activities are essential to any music programme in the Tanzanian schools. The team is further convinced that music activities must start earlier than the secondary school for a longterm change and success to be achieved. Most attitudes and interests were cultivated at the younger age and if a lasting outcome is desired then music and dance must be part of the curriculum in the primary schools in Tanzania. Even though the inclusion ofmusic in primary schools in Tanzania is outside the scope of the current CAC project, this project creates an important understanding. By looking at some of the successful achievements of international schools in the Arusha area, it is believed that Tanzanian students can be high achievers when given the right access to good teachers, resources, and opportunities.

CAC has discovered that school officials and non-music teachers are just as excited by the opportunities presented through music activities in their schools. As stated in the findings, every school that CAC has presented performances and workshops have requested for more opportunities. Schools that CAC has yet visited are asking for opportunities as well. The challenge is not so much on the desire from the youth or school officials, but the access to opportunities, resources, and qualified teachers.

\section{Phase V: \\ Developing Curriculum Resources}

This aspect of the project is still in the refining stage. Results drawn from the first few months of the initial feedback on the first curriculum resources developed will result in a final format to be applied consistently for the development of upcoming resources. The initial feedback demonstrated that teachers found the content and background information to be helpful, and they wanted more! CAC is concerned about the quality of the materials produced during the output and giving as much authentic information and context as possible. Once additional 
resources are available, the pilot programme can be expanded to other schools.

\section{CONCLUSION}

\section{AND RECOMMENDATIONS}

The original research questions were all addressed in this research:

1. Given an opportunity to learn about and participate in traditional music, will school children or students choose to become engaged in these activities? This is solidly proved through the formal and informal activities offered. Students eagerly chose to become engaged in these activities.

2. If both traditional and Western music are taught, will the students be able to learn both local and Western music skills alike? The results showed that this is possible, even though only the Western music skills are formally assessed in the national music examinations. Informal assessments are being developed to assess the traditional music skills. Despite the fact that most students tend to excel at either one or the other (either Western music or traditional music), students who worked on both have found success in both.

3. Given an opportunity to learn various music and dance at their school, will the students choose to remain more connected to their traditional culture? This research question has been harder to ascertain due to the traditional culture activities taking place not within the school compounds and school learning hours and days, but the students involved in music in the schools have voluntarily chosen to participate and connect with some traditional cultural events. Perhaps it was most notable that the school students voluntarily attended CAC regular weekly performances (given twice per week), considering the fact that some of these students had to walk several kilometres to the CAC site. It is also worth pointing out that in the last one-month training offered by CAC for secondary school students, the majority was from the Uraki Secondary School. The number of students wishing to participate exceeded the number of slots available (30). Students who were not selected have continued to visit CAC and often asked when the next opportunity was.

4. Given the generally poor academic performance in all academic subjects, will experiencing success in the music classroom build self-esteem among these students? There are a number of students who would have failed Form II completely and ended their education, except that their higher music scores allowed them to continue. This is quite significant. In addition, some music students failed every other course examination and were not successful in graduating or continuing in their formal schooling. Without seeing success in music, these students would have simply been labelled as incompetent or lazy, but their good success in music showed them something different. It is interesting to note that some of the stronger music students who failed all of their other subjects are now assisting the lead teacher, Emmanuel Ndale, in teaching music at Uraki Secondary School. These students are highly motivated and genuinely helping. Their self-esteem has not been destroyed despite the fact that they had failed all their courses except for music.

The results gathered from the four research questions demonstrate how CAC has brought a dramatic positive impact to school students from the first year of its involvement with the pilot programme at the Uraki Secondary School to present. The researchers believe that through refinement, $\mathrm{CAC}$ will be successful in engaging youth to get involved in preserving their culture and 
slowing down the cultural loss in Northern Tanzania.

Recommendations from the researchers include:

1. CAC and the Music Department at Tumaini University Makumira should continue their collaboration to develop resources and expand the teaching of music to other schools as quickly as possible. These resources should include both traditional and Western music contextualised for Tanzania.

2. CAC should continue to engage school students through informal and formal music education opportunities as much as possible.

3. Once more resources are available for both curriculum and finances, this pilot programme should be expanded to other nearby schools to help refine their programmes, to provide more practical teaching experiences for university music students, and, of course, to provide more opportunities for school students to benefit from music education.

4. CAC and the Music Department need to engage with educators from other academic institutions in Tanzania, especially the University of Dar es Salaam, and music schools, notably Music Mayday (Dar es Salaam), Dhow Countries Music Academy (Zanzibar), Kilima Music (Arusha), and Umoja Music School (Arusha) to foster more cooperative efforts and ideas in making tangible and positive changes in the national music curriculum in Tanzania.
5. Together with the above named organizations, government officials and ministries need to be engaged in this bigger picture for solution in preserving the rich culture of Tanzania.

\section{ACKNOWLEDEGMENTS}

This Cultural Arts Centre (CAC) project was funded in part by a grant from the European Union and funds raised through Tumaini University Makumira. Randall Stubbs serves as Programme Manager for $\mathrm{CAC}$ and was the grant author. He was also the Head of the Music Department from 2006 to 2015 . The university administrators who have provided support include Vice Chancellor Joseph Parsalaw, Deputy ViceChancellor for Administration Faustin Mahali, and bursar representative Eliakim Lekoringo.

The initial impetus and vision to try and make a difference in the lives of the children in the community came from the late Carol Stubbs (2018). Additional credit goes to Megan Stubbs Ndale, all the CAC staff, especially Glory Ewald, Aliko Mwakanjuki, Gabriel Olodi, Emmanuel Ndale and the dancers/musicians of CAC. Ideas and support also came from all the current and former lecturers from the Department of Music, including Seth Sululu, Emmanuel Ndale, Yen-Lin Goh, Sophia Kuyenga, Gary Sperl, Kimmo Tapanainen, Hanna Martikainen, Emmanuel Kaghondi, Jacqueline Henninger, Daris Hale, and Leena Lampinen, as well as the music students from the department.

\section{Oro NOTES aro}

1 Ministry of Education and Vocational Training. Curriculum for ordinary level secondary education in Tanzania. Dar es Salaam, Tanzania: Tanzania Institute of Education, 2013. 40 p.
2 Ministry of Education and Vocational Training. Music syllabus for secondary schools: Form I-IV. Dar es Salaam, Tanzania: Tanzania Institute of Education, 2010. 52 p. 
3 Muro E. D. Mwanafunzi wa muziki. Habari Maalum Press. Music Educators National Conference. 2004. The benefits of music education. URL:

http://www.childrensmusicworkshop.com/advocacy/benefits/ (20.11.2019).

\section{Or REFERENCES $\sqrt{O}$}

1. Akia B. No Way Out: Child Marriage and Human Rights Abuses in Tanzania. Human Rights Watch. 2014. URL: https://www.hrw.org/report/2014/10/29/no-way-out/child-marriageand-human-rights-abuses-tanzania (20.11.2019).

2. Auh Y. Harmony Nation Education: One Nation, One World, One Universe (Tanzania Edition, Flute Book 1). Korea: Music 4 One, 2013. 157 p.

3. Browning M. Shake it: A Sudy of Traditional Dance and Drumming in Tanzania with the Africa Traditional Dance Group. 2009.

URL: https://igitalcollections.sit.edu/cgi/viewcontent.cgi?referer=https://www.google.com/\&httpsredir= $1 \&$ article $=1650 \&$ context $=$ isp_collection (20.11.2019).

4. Fratkin E., Wu T. S. M. Maasai and Baarabaig Herders Struggle for Land Rights in Kenya and Tanzania. Cultural Survival Quarterly. 1997. URL:

https://www.culturalsurvival.org/ourpublications/csq/article/maasai-and-barabaig-herdersstruggle-land-rights-kenya-and-tanzania (20.11.2019).

5. Haji M. Youth Employment in Tanzania: Taking Stock of the Evidence and Knowledge Gaps. Ottawa, Canada: International Development Research Center, 2015. 40 p.

6. Henninger J. Music Education in Tanzanian Schools. Connections. 29 (1). 2014, pp. 8-10.

7. Ho Y. C., Cheung, M. C., \& Chan, A. Music Training Improves Verbal but not Visual Memory: Cross-Sectional and Longitudinal Explorations in Children. Neuropsychology. 12. 2003, pp. 439-450.

8. Kiel H., Haonga E. (Eds.). Ukuti, ukuti (book and CD). Zanzibar: Mkuku na Nyota, 2011. $17 \mathrm{p}$.

9. Mapana K. Music Traditions in the School Curriculum: Attitudes of Tanzanian Music Educators (Doctoral Dissertation). 2013. ProQuest Digital Dissertations. 99 p.

10. Mapana K. Transitions in the Social Functions of the Muheme Music Tradition of the Wagogo People of Dodoma, Tanzania. International Journal of Humanities and Social Science. 3 (3), 2013, pp. 161-168.

11. Mwakanjuki A. E. Mapping of Maasai, Meru, and Chagga Traditional Music in Northern Tanzania. Makumira, Tanzania: Cultural Arts Centre, 2014. 17 p.

12. National Examination Council of Tanzania. Uraki secondary school 2015 examination results. URL: http://necta.go.tz/matokeo/ftna2015/html/S1229.htm (20.11.2019).

13. Nonnyonga-Tamasuza S., Solomon T. (Eds.). Ethnomusicology in East Africa: Perspectives in Uganda and Beyond. Kampala, Uganda: Fountain Publishers, 2012. 255 p.

14. Rabkin N., Redmond R. The Art of Education Success. Washington Post. A19, 2005. 16 p.

15. Shehan-Campbell, P., Wiggins T. Oxford Handbook of Children's Musical Cultures. London: Oxford, 2013. 636 p.

16. Siwale E., Sefu M. Development of Primary Education in Tanzania. Ontario, Canada: Brock University, 1977. 71 p.

17. Strumpf M. Music Education in Malawi and Zimbabwe [paper presented in Grahamstown, South Africa]. 2001. URL:

http://portal.unesco.org/culture/en/files/19554/10813425843strumpf.pdf/strumpf.pdf(20.11.2019).

18. Strumpf M. Different Approaches to Music Education in East Africa: The past 100 years. 2015. 
URL: http://musicinafrica.net/music-education-tanzania-100-years-different-approaches (20.11.2019).

19. Stubbs R. Traditional Music and Dance Preservation and Promotion in Northern Tanzania: Year Two Report for the European Development Fund. Cultural Arts Centre Makumira, Tanzania, 2016. 118 p.

20. Taylor P., Mulhall A. Contextualising Teaching and Learning in Rural Primary Schools: Using Agricultural Experience. Education Research. 1 (20). 1977. 130 p.

URL: http://collections.infocollections.org/ukedu/en/d/Jdep20b/7.1.1.2.html (20.11.2019).

21. UNESCO. Intangible Heritage Domains: Performing Arts (Such as Traditional Music, Dance, and Theatre). 2016. URL: http://www.unesco.org/culture/ich/en/performing-arts-00054 (20.11.2019).

22. University of Pennsylvania African Studies Center. East Africa Living Encyclopedia: Tanzania Ethnic Groups. 2016. URL: https://www.africa.upenn.edu/NEH/tethnic.htm(20.11.2019).

23. US Department of Education. Getting Ready for College Early: A Handbook for Parents of Students in the Middle and Junior High Schools Years. Washington, D. C: US Government Publications, 1997. 20 p.

24. World History at KMLA. Tanganyika a British Mandate 1918-1939.

URL: http://www.ntz.info/gen/b00627.html\#id03484 (20.11.2019).

About the authors:

Randall N. Stubbs, Programme Manager, Cultural Arts Centre, Tumaini University Makumira (P.O. Box 55, Usa River, Tanzania),

ORCID: 0000-0003-3258-5747, manager@cac.makumira.ac.tz

Yen-Lin Goh, DMA (Doctor of Musical Arts), Director, Passiontree Music (58200, Kuala Lumpur, Malaysia), ORCID: 0000-0002-8993-1340, yenlin.goh@gmail.com

Об авторах:

Стаббс Рэндалл Н., программный менеджер, Центр культуры и искусств, Университет Тумаини Макумира (Р. О. Вох 55, г. Уса Ривер, Танзания),

ORCID: 0000-0003-3258-5747, manager@cac.makumira.ac.tz

Ен-Лин Го, DMA (доктор музыки), директор, «Passiontree Music» (58200, г. Куала-Лампур, Малайзия),ORCID: 0000-0002-8993-1340, yenlin.goh@gmail.com 